\title{
Taxonomic and Functional Structure of Phytophagous Insect Communities Associated with Grain Amaranth
}

\section{S Niveyro \& A Salvo}

\section{Neotropical Entomology}

ISSN 1519-566X

Volume 43

Number 6

Neotrop Entomol (2014) 43:532-540 DOI 10.1007/s13744-014-0248-3

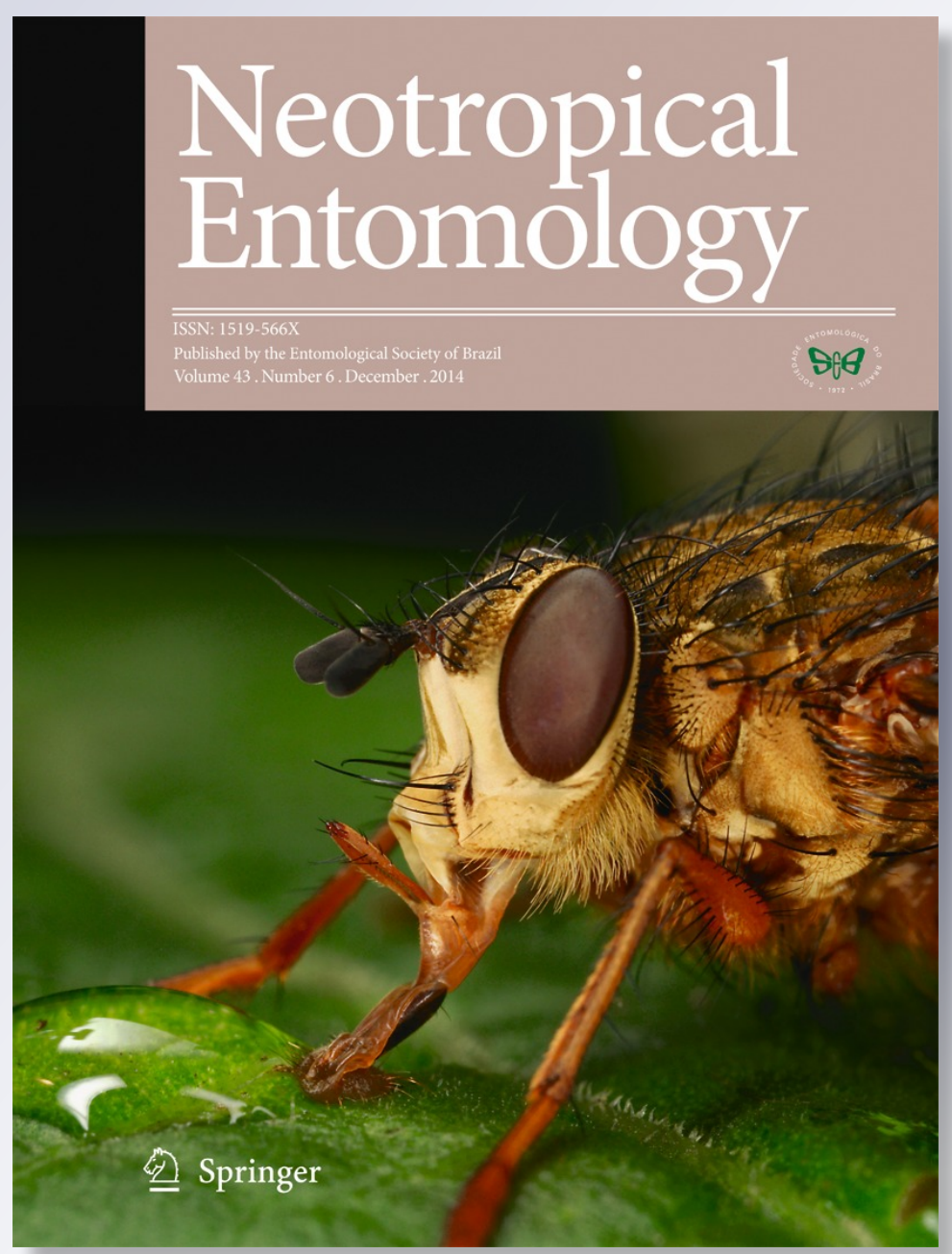

包 Springer 
Your article is protected by copyright and all rights are held exclusively by Sociedade Entomológica do Brasil. This e-offprint is for personal use only and shall not be selfarchived in electronic repositories. If you wish to self-archive your article, please use the accepted manuscript version for posting on your own website. You may further deposit the accepted manuscript version in any repository, provided it is only made publicly available 12 months after official publication or later and provided acknowledgement is given to the original source of publication and a link is inserted to the published article on Springer's website. The link must be accompanied by the following text: "The final publication is available at link.springer.com". 


\title{
Taxonomic and Functional Structure of Phytophagous Insect Communities Associated with Grain Amaranth
}

\author{
S NIVEYRo ${ }^{1}$, A SALVO $^{2}$ \\ ${ }^{1}$ Fac de Agronomía, Univ Nacional de La Pampa, Santa Rosa, La Pampa, Argentina \\ ${ }^{2}$ Centro de Investigaciones Entomológicas de Córdoba, Instituto Multidisciplinario de Biología Vegetal, CONICET, Fac de Ciencias Exactas \\ Físicas y Naturales, Univ Nacional de Córdoba, Córdoba, Argentina
}

\section{Keywords}

Amaranthus, herbivory, insect guilds, stem borer

\section{Correspondence}

S Niveyro, Fac de Agronomía, Univ Nacional de La Pampa, Santa Rosa, La Pampa, Argentina; niveyro@agro.unlpam.edu.ar

Edited by Antônio R Panizzi - Embrapa/Trigo

Received 8 April 2014 and accepted 6 October 2014

Published online: 13 November 2014

(C) Sociedade Entomológica do Brasil 2014

\begin{abstract}
Amaranthus are worldwide attacked mainly by leaf chewers and sucker insects. Stem borers and leaf miners follow in importance, while minor herbivores are leaf rollers, folders, and rasping-sucking insects. The herbivorous community observed on Amaranthus spp. in Argentina was consistent with the information reported worldwide both in guild composition and order proportion. Amaranth plants had a higher number of phytophagous species in their native rather than in its introduced range. Occurrence of insect guilds differed in space and time. The highest density of leaf chewers was observed shortly after the emergence of plants, while higher density of borer and sucker insects coincided with reproductive stages of the crop. The sucking guild was observed mainly at panicles, while the insects within the leaf chewer group were registered in both leaves (92.6\%, $n=746$ adults) and inflorescences (7.4\%). The borer guild was also recorded in stems and inflorescences; however, the density of larvae in stems was about four times as high as the density observed in panicles ( $n=137$ larvae).
\end{abstract}

\section{Introduction}

In the last decades, amaranth has received renewed interested as a food crop. This is largely due to the high amounts of good quality proteins for human consumption contained in its grains (Downton 1973, Teutonico \& Knorr 1985). Its amino acid profile, and in particular the high levels of lysine, makes amaranth grains an attractive protein source, very similar to the recommended amino acid pattern required for human nutrition, as established by FAO and the World Health Organization (Becker et al 1981, Pedersen et al 1990). Moreover, being a pseudocereal, grains of amaranths lack gluten, thus being a suitable food for people with gluten intolerance (Zannini et al 2012). But Amaranthus plants are not only recognized for their nutritional features but also due to their ability to thrive in many environments and tolerate adversities such as low water regime (Liu \& Stützel 2002), poor soils, and moderate salinity levels (Omami \& Hammes 2006), conditions on which other commercial crops are not able to grow (Brenner et al 2000, Johnson \& Henderson 2002).

Numerous herbivorous insects have been reported to affect the Amaranthus genus worldwide (El-Aydam \& Bürki 1997). Among them, species of leaf chewers and sucking insects are known to feed heavily on leaves and floral buds (Bürki et al 1997, Olson \& Wilson 1990), whereas the stem borer guild is mentioned as the prevalent group at global scale (Louw et al 1995). Leaf miners, leaf rollers, and leaf folders are also mentioned as amaranth insect feeders. For the first group, species are usually reported in Amaranthus wild plants rather than in crops (Stegmaier 1950, Spencer 1973, Mujica \& Berti 1997, Carrasco 1987), while little is known about the species in the leaf roller and folder guilds (Jena et al 2000, Waterhouse 1994). Although Amaranthus is a genus that is widely distributed around the world, most of the species (including those cultivated for grain purpose) have originated in the Americas (Sauer 1950, 1967, Coons 1982), while only a few of them are native to Europe, Asia, and Africa (Sauer 1967, Robertson 1981, Costea et al 2001). 
For it being an introduced crop in many non-American countries, grain amaranth might experience a reduction of herbivorous insect richness in introduced ranges according to the "enemy release hypothesis" (ERH) (Keane \& Crawley 2002). This would represent an advantage for its cultivation in non-natural areas. However, comparative studies regarding herbivore diversity, load, and herbivory damage on Amaranthus spp. in the Americas and elsewhere are not available. In turn, few studies concerning phytophagous insects on grain amaranth has been published in South America (Ves Losada \& Covas 1987, Guerrero et al 2000, de Oliveira et al 2012, Riquelme et al 2013), which is considered the original region of two cultivable species Amaranthus cruentus and Amaranthus mantegazzianus (Sauer 1950, 1967). Therefore, the first aim of this study was to inventory and describe the community of phytophagous insects associated to grain amaranth in Argentina, exploring the occurrence of insect guilds along the phenological cycle of the crop. The second aim was to compare the Amaranthus phytophagous insect fauna in American and non-American countries on the basis of a literature survey, focusing the analysis on its taxonomic and guild structure.

\section{Material and Methods}

\section{Field surveys}

Field surveys of phytophagous insects were conducted in crops of three amaranth species (Amaranthus cruentus cv. Don León, Amaranthus hypochondriacus cv. Artasa 9122, A. hypochondriacus San Antonio, A. hypochondriacus FK 280-FH1, and $A$. mantegazzianus cv. Don Juan) sowed in the north of Santa Rosa, La Pampa, Argentina $\left(36^{\circ} 37^{\prime} \mathrm{S}\right.$, $64^{\circ} 16^{\prime} \mathrm{W}$ ), during two growing seasons (summer 20072008 and 2008-2009). A field of $156 \mathrm{~m}^{2}$ was sowed with a space of $0.50 \mathrm{~m}$ between rows and a density of $3.5 \mathrm{~kg}$ of seeds per hectare. The plants did not receive any insecticide application and weeding was done manually. The essay was located in a livestock area characterized by grasslands, wheat, and alfalfa field crops. During two growing seasons, the essay was performed in a field of 7 ha in which several weeds were present, being Cynodon dactylon, Digitaria sanguinalis, Portulaca oleracea, Xanthium cavanillesii, Salsola kali, and Conyza bonariensis the most abundant.

Insect sampling was conducted shortly after the plant emergence and through all the crop cycle. Five samples in the first year and seven in the second year were performed during daytime (9:00 AM to 2:00 PM approximately), when most of the herbivorous insects are active. On three occasions in summer 2008, observations were made at night (9:00 PM to $10 \mathrm{PM}$ ) to sample phytophagous insect not observed during daytime. In each sampling date, 250 plants were selected randomly and the whole plants were inspected. The insects observed were counted and collected (at least one sample of each species) for later identification in the laboratory. The growing stage of the insects and the location where they were found in the plant were also registered.

During the second year of the trial (summer 2008/2009), borer insect occurrence was recorded. For that, a total of 500 plants were taken at random in two different stages of the plant coincident with stages R4 and R6, according a phenological scale (Mujica \& Quillahuamán 1989). The stalks and panicles of these plants were sectioned longitudinally, and active larvae were counted and preserved in $70 \%$ ethanol for identification.

\section{Literature survey}

A literature survey of phytophagous insects associated to Amaranthus spp. was carried out, including research articles, reviews, and catalogs mentioning insects on both wild and cultivated amaranth plants. Only herbivorous insects that were reported as effectively feeding on plants were considered, and they were grouped into different guilds mainly following Stork (1987).

\section{Statistical analysis}

The chi-square test was performed to compare guild structure and abundance between phytophagous communities observed in the Americas and those recorded in other parts of the world. The same analysis was performed to compare herbivore communities in Argentina with the information recorded worldwide. In all cases, an alpha of 0.05 was used.

\section{Results}

Seventy previous studies on herbivorous fauna associated to Amaranthus plants made in 33 countries (42 in America and 28 elsewhere) on the five continents reported 255 species of phytophagous insects. The guild of leaf chewer was the largest and richest group worldwide (El-Aydam \& Bürki 1997, Clarke-Harris et al 2004, Aragón-García et al 2011), representing half of the total insect species recorded feeding on amaranth (Fig 1a). The remaining species were distributed among sucking insects (28\%), stem borer (9\%), leaf miner $(8 \%)$, and three minor guilds: rasping-sucking insects (3\%), leaf folder, and leaf roller (1\% each) (Fig 1a). Species in the leaf chewer guild belonged to 21 families of insects, while the leaf folder guild was just represented by two species in one family (see Table 1 in the Online Supplementary Material). 
Fig 1 Guild structure of herbivorous insect assemblages associated with plants of Amaranthus spp. worldwide (a) and in Argentina (b).

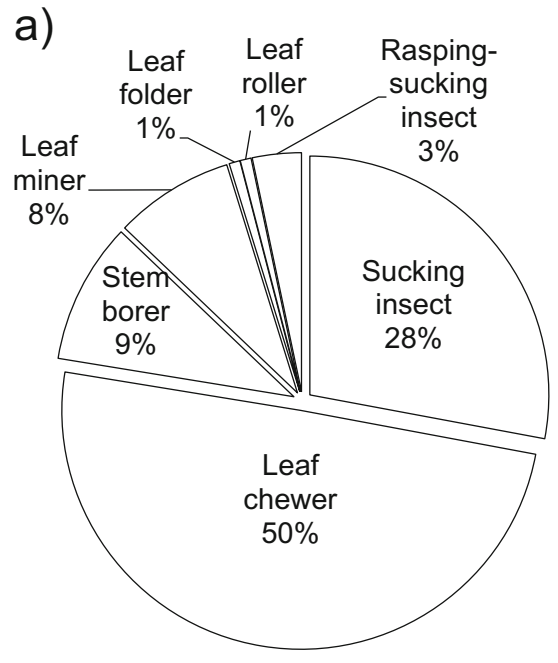

$N=255$ b)

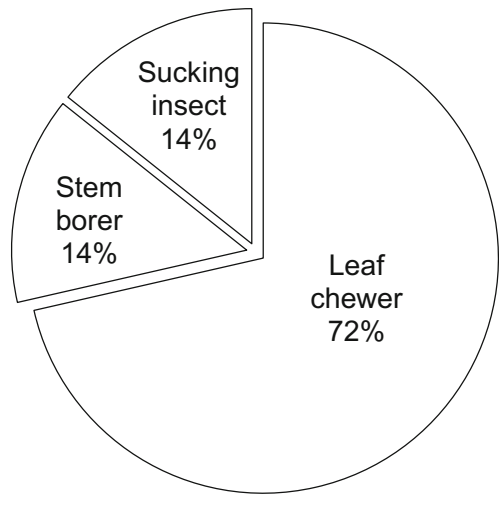

$\mathrm{N}=19$
Amaranth plants had a higher number of phytophagous species in their native than in their introduced range $\chi^{2}$ guild $=$ 12.69, $d f=6, p_{\text {guild }}=0.04$ ), the leaf chewer, the sucking, and the leaf roller guilds being represented in average by about twice as many species as in the Americas (Fig 2). In contrast, none of the species of leaf folder were present in the American continent and the number of species within the stem borer, and the rasping-sucking guilds were lower in the native range of Amaranthus than elsewhere. There was no difference in the taxonomic structure on herbivore communities based in the number of species in each order $\left(\chi_{\text {order }}^{2}=\right.$ 9.59, $\left.d f=5, p_{\text {order }}=0.08\right)$. Worldwide, the orders Coleoptera, Lepidoptera, and Hemiptera had the largest number of species cited on Amaranthus plants, while Diptera, Orthoptera, and Thysanoptera represented the smaller groups (Fig 3a).

In Argentina, we gathered a total of 1,759 insects feeding on amaranth plants in the two sampling periods, $44 \%$ belonged to the guild of sucking herbivores, $46 \%$ to the leaf chewer guild, and $10 \%$ were stem or panicle borers (Fig 4). The sampled insects belonged to 19 species, the leaf chewer being the most abundant and speciose guild (Figs $1 \mathrm{~b}$ and $4 \mathrm{a}$ ). The three species included in the borer guild behave as leaf chewer insects in adult stage.

Within the leaf chewer guild, Epicauta adspersa (Klug), Achyra similalis (Guenée), and Naupactus verecundus Hustache were the most abundant species representing $53 \%, 15 \%$, and $13 \%$ of defoliating insects, respectively (Fig 4a). The pentatomid Chinavia musiva (Berg) was the most common insects among sucking herbivores representing $99 \%$ of the individuals in this group (Fig 4C), while Conotrachelus histrio Boheman, Conotrachelus cervinus Hustache, and Aerenea quadriplagiata Boheman were the only three borer species found (Fig 4 b).

The three borer species were observed in the evening hours, and both $C$. histrio and $C$. cervinus were always observed in pairs in mating activities.
Fig 2 Comparison of insect species guilds associated to Amaranthus spp. in their native and introduced ranges. Error bars represented \pm standard error.

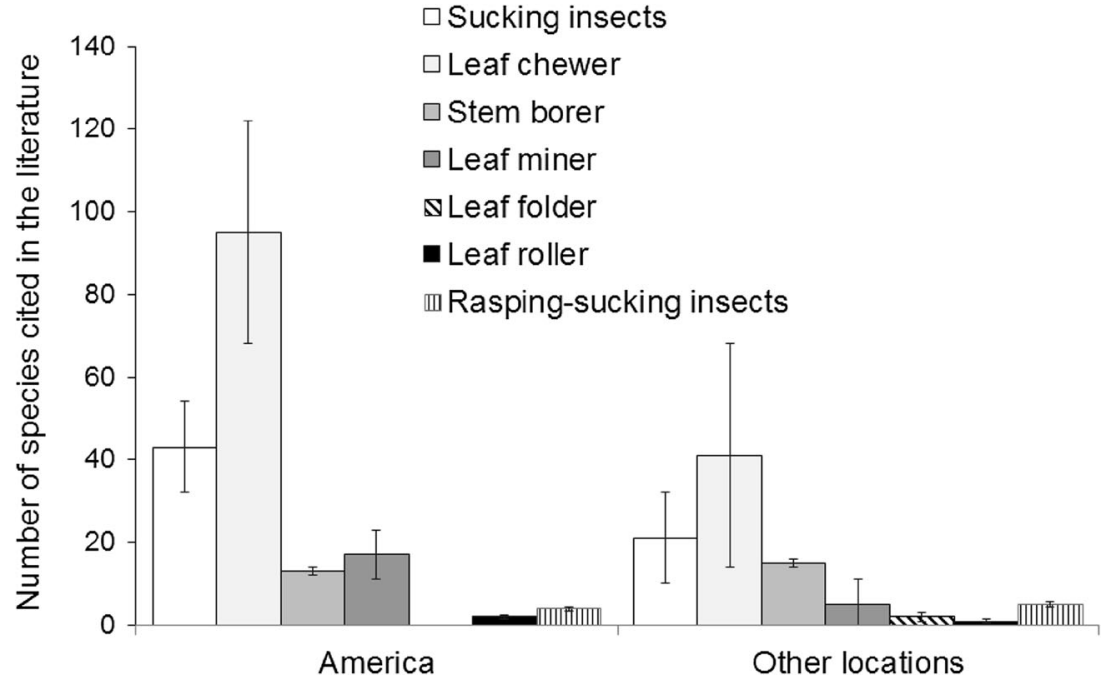


a)

$N=255$

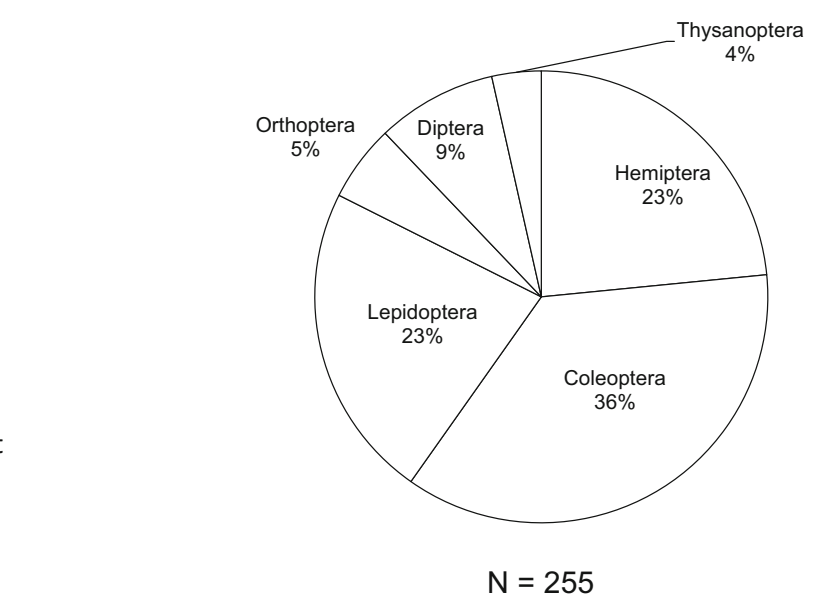

b)

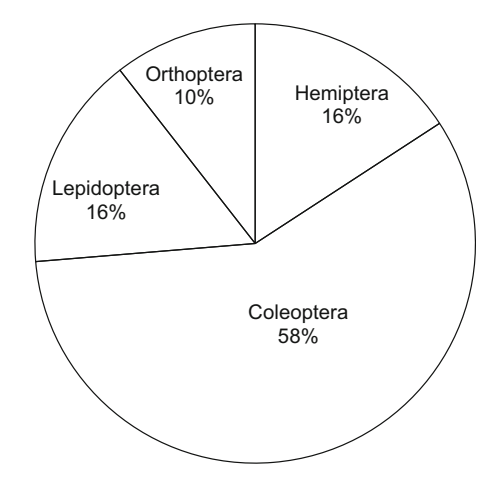

$N=19$

)

Fig 3 Taxonomic order of insect species cited in plants of and observed in amaranth grain in Argentina (b).

(

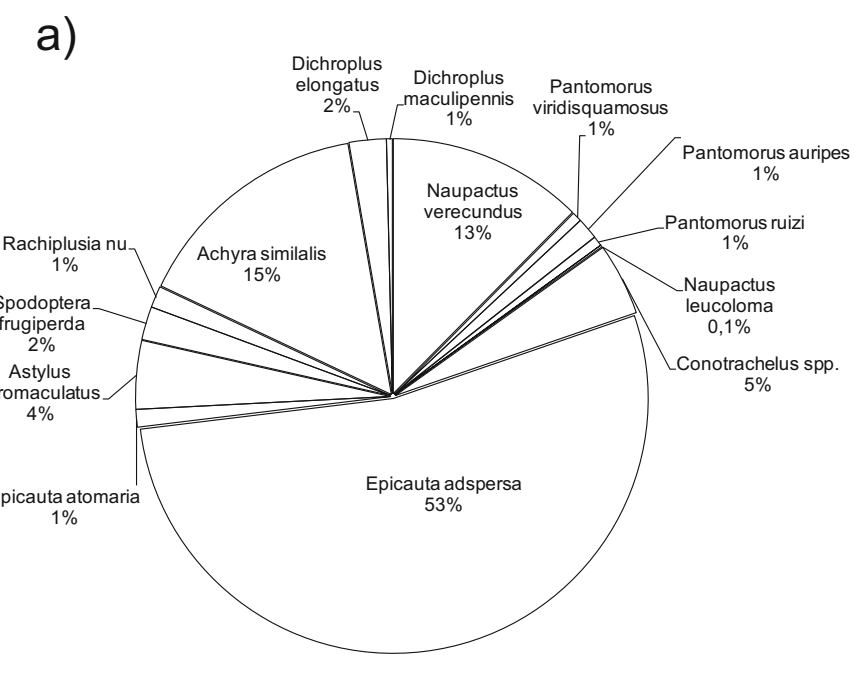

$N=806$ b)

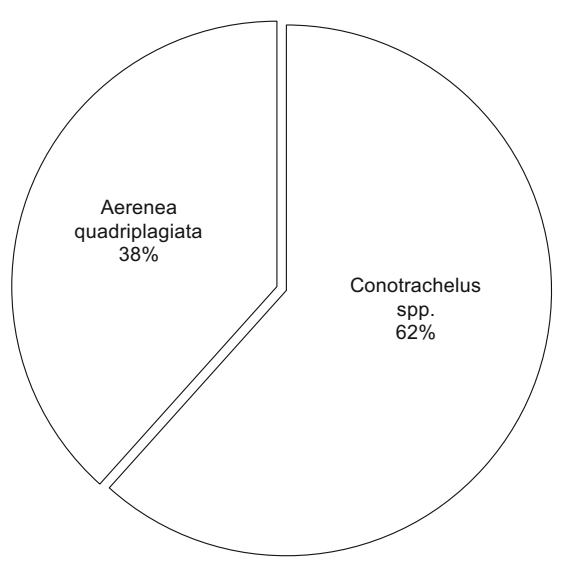

$\mathrm{N}=172$

c)

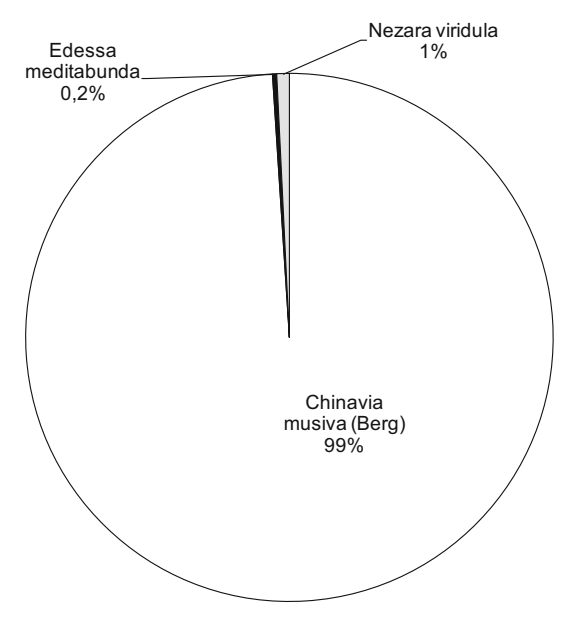

$\mathrm{N}=781$

Fig 4 Insect species observed feeding in Amaranthus plants in Argentina: a leaf chewers, $\mathbf{b}$ stem borers, and $\mathbf{c}$ sucking insects. 
The sucking guild was observed at panicles while those insects included as leaf eaters were registered in both leaves (92.6\%, $n=746$ adults) and inflorescences $(7.4 \%)$, whereas borer insects were found in stems and inflorescences. Of the total plants examined, $63.8 \%(n=319)$ were affected by borer insects. The density of larvae in stems was about four times as high as the density observed in panicles ( $n=137$ larvae). Guild density fluctuated at different stages of crop development: the highest density of borer and sucker insects was observed in the reproductive phase of the plant, whereas leaf eater insects were recorded from emergence of the plants until physiological maturity of the panicles (Fig 5).

The herbivore community observed on Amaranthus spp. in Argentina did not differ from that recorded in other countries neither in guild composition $\left(\chi_{\text {guild }}^{2}=5.06, d f=6\right.$, $p_{\text {guild }}=0.53$; Fig 1) nor in proportion of species within orders $\left(\chi_{\text {order }}^{2}=6.05, d f=5, p_{\text {order }}=0.29 ;\right.$ Fig 3$)$.

\section{Discussion}

\section{Community of herbivores worldwide}

Leaf chewer and sucker insects are the most abundant herbivores on Amaranthus plants worldwide. Chrysomelidae, Noctuidae, and Curculionidae were the most important families among the chewers, while Cicadellidae and Miridae dominate the sucker guild. The stem borer and the leaf miner guilds followed in abundance, with a similar percentage of $9 \%$ and $8 \%$ of the total of insects, respectively. Both guilds were represented by few families, more than $76 \%$ of the borer species belong to Curculionidae, while a similar percentage of leaf miner species belong to Agromyzidae and Anthomyiidae (both Diptera). Even though stem borers represented a small fraction of the total insects, they usually produce severe damage on cultivated amaranth (Terry \& Lee 1990, Jha et al 1992, Louw et al 1995, vdM Louw \& Myburgh
Fig 5 Occurrence and density of phytophagous guilds observed at phenological stages of plant. Appearance of plants at each stage is illustrated in the table at the top of the figure.

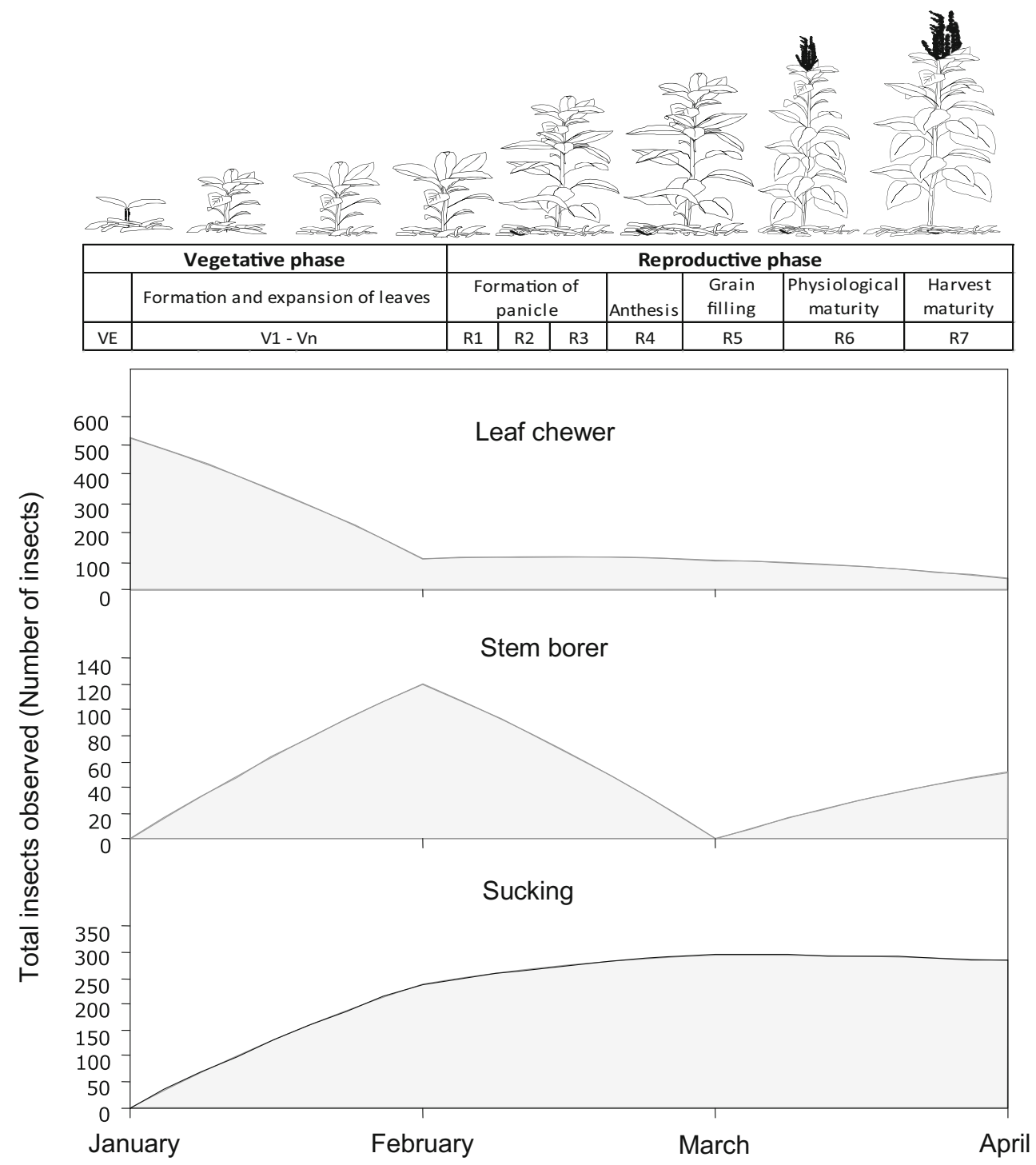


2000, Salas-Araiza \& Boradonenko 2006) unlike leaf miners, which are referred mostly on wild types (Stegmaier 1950, Spencer 1969, Spencer \& Havraneck 1989, Alex \& Heal 1994). The stem borer guild in their larval stages makes galleries in the main stems, but depending on the species, it could also be on the smaller secondary stems, thicker leaf petioles, and even in roots (Wilson 1990, Louw et al 1995). In contrast, occurrence of leaf folder, roller, and rasping-sucking insects is sporadic, and scarce information related to the damages produced by these groups on Amaranthus crops may be found (Stegmaier 1950, Waterhouse 1994, Jena et al 2000).

The studies on herbivorous fauna associated to Amaranthus spp. indicated that amaranth plants in introduced ranges (non-American countries) seem to sustain a reduced number of herbivorous insect species within each guild $\left(\chi^{2}=12.69, d f=6, p=0.04\right)$. Although this may be due in part to the greater number of studies conducted on the insect fauna of amaranth in America $(n=42)$ than elsewhere $(n=28)$, the results coincide with the predictions of the hypothesis of the release of natural enemies (Keane \& Crawley 2002). The leaf miner guild showed a higher loss of species than ectophytophagous insects (chewer and sucker insects). This agreed with a previous report that indicated plants in introduced areas were less attacked by specialists and endophytophagous insects (Liu \& Stilling 2006). Since they establish a close relationship with the host plant, it is expected they need more time to develop in a new host. Nevertheless, this was not observed for the stem borer guild that presented more herbivore species outside the Americas. Considering that plants of the genus Amaranthus are particularly vulnerable to this insect guild and several species were documented from Africa and Europe (Louw et al 1995, Bürki et al 1997, Anno-Nyako et al 1991, Clarke-Harris et al 2004, Banjo 2007, Gültekin \& Korotyaev 2012), it is possible that amaranth plants may recruit new species belonging to this guild in the introduced ranges (Bürki \& Nentwig 1997). Herbivore species richness in a geographic range may be influenced by many factors, e.g., geographical distribution of the plant, structure and interactions within communities, and sampling efforts, among others (Strong et al 1984, Colautti et al 2004); thus, it should be considered that the list of insects associated to Amaranthus is still incomplete, especially in South and Central America where minor guilds are scarcely studied, and no information about damage levels by different guilds on cultivable amaranth are available.

\section{Community of herbivores in Argentina}

Proportions of species observed for each guild and each insect order in Argentina were consistent with the reported worldwide $\left(\chi_{\text {guild }}^{2}=5.06, d f=6, p_{\text {guild }}=0.53 ; \chi_{\text {order }}^{2}=6.05, d f=\right.$ $\left.5, p_{\text {order }}=0.29\right)$. Only the three most important guilds were found, leaf chewer, sucker, and stem borer insects, whereas the three major orders Coleoptera, Lepidoptera, and Hemiptera were present along with Orthoptera. The relative abundance of species and the occurrence of families in each guild varied between our results and those found in other studies around the world, but most prominent families in the major guild were present in our results.

In the leaf chewer guild, Meloidae (Coleoptera) represented $54 \%$ of the individuals. Epicauta adspersa (Klug) was the most abundant defoliator. This species was present throughout the growing season and caused severe defoliation mainly in the early stage of the crop (January) when it compromised the initial stand of plants. Meloid beetles have been previously reported in amaranth plants displaying similar voracity as E. adspersa in Argentina, e.g., Epicauta leopardina Haag in Paraguay (Schuester 1987) and Epicauta cinerea Föster in A. hypochondriacus in Mexico (Pérez-Torres et al 2011). Epicauta atomaria (Germar, 1821) in turn occurred sporadically at very low densities. The abundance of meloid beetles here observed coincides with previous reports in amaranth plants (Kauffman \& Weber 1990, Henderson et al 1993, Pérez-Torres et al 2011).

Lepidopteran larvae are another important group of defoliators, always observed feeding on leaves. In our samples, A. similalis (Guenée, 1854) (Crambidae) was the most abundant species. Larvae of this species produced a fine silk and slight curving of the leaf blade. Besides leaves, it has been indicated that $A$. similalis consumes panicles causing agglomeration of floral structures (Guerrero et al 2000), but this type of damage was not observed in our study. Instead, we observed cut floral branches in some plants, but we could not determine whether it was made by $A$. similalis or by Astylus atromaculatus Blanch (Coleoptera: Melyridae), another species commonly found in inflorescences. In addition to larval stages, we observed many adults of $A$. similalis on the crop. Pupae of this species on weedy Amaranthus retrofexus and all insect stages in $A$. cruentus were previously reported (Stegmaier 1950, Guerrero et al 2000), which strongly suggests that this species is able to fully develop in plants of the Amaranthus genus. Spodoptera frugiperda (Smith) and Rachiplusia nu (Guenée) (Noctuidae) were present in a similarly lower density, both of them are well-known pest species in corn and sunflower, and they were previously reported in both crop and weedy amaranth species (Stegmaier 1950, Clarke-Harris et al 2004, Guerrero et al 2000). The low densities of these species here recorded suggest that amaranth is an alternative but not their preferred food plant in the study region. Similarly, species of grasshoppers Dichroplus maculipennis (Blanch) and Dichroplus elongates Giglio-Tos were observed sporadically, at densities that produced no significant damages. However, given the polyphagy of these species, it should not be discarded that they may be potential pests for this crop given 
that several species of acridids were cited feeding on Amaranthus worldwide (Baloch et al 1981, Stegmaier 1950, Jena et al 2000, Pérez-Torres et al 2011).

Astylus atromaculatus and weevils of the species $N$. verecundus Hustache and Pantomorus ruizi (Brèthes) (Coleoptera: Curculionidae) consumed both panicles and leaves. The present study is the first to mention of A. atromaculatus in cultivated amaranth, although these species have been mentioned feeding on the weed Amaranthus hybridus (vdM Louw \& Myburgh 2000). Weevils were the second largest group of insects after meloid beetles, representing about $22 \%(n=157)$ of the leaf chewer guild. Several species of weevils feed heavily on both cultivated and weedy Amaranthus (Vasicek et al 1998, ElAydam \& Bürki 1997, Louw et al 1995), some of them considered as potential agents for biological control of amaranth weeds (Napompeth 1982, Kolaib et al 1986). Among the species recorded in adult stage, $N$. verecundus was the dominant one, followed by Conotrachelus spp. and Pantomorus auripes Hustache. Besides defoliator weevils, two stem borer species, Conotrachelus cervinus Hustache and C. histrio Boheman, caused significant damages. The first species was previously recorded in Argentina on cultivars of Amaranthus but only as leaf feeder (Ves Losada \& Covas 1987), without any mention about its stem borer habit. Conotrachelus histrio, on the other hand, was identified as an efficient agent for biocontrol of the weed Amaranthus quitensis in soybean crops due to the intense drilling that their larvae produce in the plants (Vasicek et al 1998). Conotrachelus histrio found in plants of Amaranthus in Argentina has sometimes been referred to as a synonym of Conotrachelus coelebs Boheman; however, these are two different species, confused since 1986 (Dr. Charles O'Brien, personal communication). Within the borer guild, a third species was found: A. quadriplagiata Boheman (Coleoptera: Cerambycidae). All borer species found in our study have been previously reported feeding in different species of the genus Amaranthus (Bosq 1943, Ves Losada \& Covas 1987, Vasicek et al 1998, Riquelme et al 2013); however, we reported for the first time the three species affecting the same stems. The borer guild damage was very noticeable in February, coinciding with advanced stages of the crop, when about $64 \%$ of the plants sampled were damaged. The most affected plant parts were main stems, where we found the greatest number of larvae, and it was continued throughout the rachis of the inflorescence. Surprisingly, only a few studies reported a reduction of grain yield in plants with drilled stems (Phogat et al 1994), possibly due to larvae not affecting the vascular part of the plant (Bürki et al 1997). However, borer guild causes loss of seeds in amaranth crop by downfall of plants due to the weakening of stems and roots depending on the feeding site, belowground plant parts, e.g., Hypolixus spp., Baris cf. dodoris
Marshall (Louw et al 1995), Lixus camerunus Klobe (AnnoNyako et al 1991), or above-ground plant parts (stem or panicles) as it happened in our study.

Among sucking insects, the occurrence of the species Edessa meditabunda and Nezara viridula was occasional, while C. musiva (Berg) contributed with almost $99 \%$ of all the insects observed. The latter species was recorded from January, and its density increased rapidly in the flowering stage and kept constant until the grain filling stage. All individuals were concentrated on panicles, where they fed on immature seeds and possibly sap of floral branches. According to literature, several species, mostly in Aphididae (aphids) and Cicadellidae (leafhoppers) but also in Coreidae, Lygaeidae, and Miridae, occur in weedy amaranth species (El-Aydam \& Bürki 1997, Bürki et al 2001). In cultivated amaranths, Miridae, Pentatomidae, and Coreidae are the most frequently found families (El-Aydam \& Bürki 1997, Salas-Araiza \& Boradonenko 2006, Aragón-García et al 2011, Pérez-Torres et al 2011). Miridae, mainly species of the genus Lygus (Lygus pratensis L., Lygus rugulipennis Poppius, L. spp.), are mentioned in cultivated amaranth (Jena et al 2000, Louw \& Myburgh 2000, Salas-Araiza \& Boradonenko 2006), Lygus lineolaris (Palisot de Beauvois) being the typical pest species of amaranth in the North America (Weber et al 1988, Olson \& Wilson 1990).

Acknowledgments We thank Dr Charles O'Brien for the identification of the Conotrachelus species and the information provided and Dr. Eduardo Faundez for his help in identifying C. musiva (Berg).

Electronic supplementary material The online version of this article (doi:10.1007/s13744-014-0248-3) contains supplementary material, which is available to authorized users.

\section{References}

Alex JF, Heal KP (1994) Preliminary investigations towards the biological control of annual weeds of row crops in Ontario. In: Final report for the Agricultural Research Institute of Ontario. University of Guelph, ON, 114 pp

Anno-Nyako FO, Adebanjo A, Agunloye O (1991) Brown rot and die-back disease induced by a curculionid (Lixus camerunus Klobe) in amaranth (Amaranthus hybridus L.) in Nigeria. Ghana J Agric Sci 24:87-92

Aragón-García A, Huato MAD, Huerta-Lara M, Sáenz-de-Cabezón FJ, Pérez-Moreno I, Marco-Mancebón V, López-Olguín JF (2011) Insect occurrence and losses due phytophagous species in the amaranth Amaranthus hypochondriacus L. crop in Puebla, Mexico. Afri J Agric Res 6:5924-5929

Baloch GM, Khan AG, Zafar T (1981) Natural enemies of Abutilon, Amaranthus, Rumex and Sorghum in Pakistan. In: Commonwealth Institute of Biological Control. Report September 1975-September 1980, Pakistan Station, Rawalpindi, Pakistan, 88 pp

Banjo AD (2007) Bio-ecology and life history of Gasteroclisus rhomboidalis Boh. (Coleoptera: Curculionidae): a pest of Amaranthus cruentus (L.) Sauer. J Entomol 4:308-316 
Becker R, Wheeler EL, Lorenz K, Stafford AE, Gilosjean OK, Betschart AA, Saunders RM (1981) A compositional study of amaranth grain. J Food Sci 46:1175-1180

Bosq JM (1943) Segunda lista de coleópteros de la República Argentina dañinos a la agricultura. Direc. Sanidad Vegetal. Minist Agric Nación 4: $1-80$

Brenner D, Baltensperger D, Kulakow P, Lehmann J, Myers R, Slabbert $M$, Sleugh B (2000) Genetic resources and breeding of Amaranthus. Plant Breed Rev 19:227-285

Bürki CB, Nentwig W (1997) Comparison of herbivore insect communities of Heracleum sphondylium and $H$. mantegazzianum in Switzerland (Spermatophyta: Apicaceae). Entomol Gen 22:147-155

Bürki HM, Schroeder D, Lawrie J, Cagáň L, Vráblová M, El-Aydam M, Szentkiralyi F, Ghorbani R, Jüttersonke B, Ammon HU (1997) Biological control of pigweeds (Amaranthus retroflexus L., A. powellii S. Watson and $A$. bouchonii Thell.) with phytophagous insects, fungal pathogens and crop management. Integr Pest Manag Rev 2:51-59

Bürki HM, Lawrie J, Greaves MP, Down VM, Jüttersonke B, Cagán L, Vráblová M, Ghorbani R, Hassan EA, Shroeder D (2001) Biocontrol of Amaranthus spp. in Europe: state of the art. Biocontrol 46:197-210

Carrasco F (1987) Insects in kiwicha field of Cusco and Apurimac (Peru). Rev Peru Entomol 30:557-562

Clarke-Harris D, Fleischer SJ, Fuller C, Bolton J (2004) Evaluation of the efficacy of new chemistries for controlling major lepidoptera pests on vegetable amaranth in Jamaica. CA RDI Rev 4:12-19

Colautti RI, Ricciardi A, Grigorovich IA, Maclsaac HJ (2004) Is invasion success explained by the enemy release hypothesis? Ecol Lett 7:721733

Coons MP (1982) Relationships of Amaranthus caudatus. Econ Bot 36: 129-146

Costea M, Sanders A, Waines G (2001) Preliminary results toward a revision of the Amaranthus hybridus species complex (Amaranthaceae). SIDA, Contrib Bot 19:931-974

de Oliveira CM, Ribeiro Junior WQ, de Camargo AJA, Frizzas MR (2012) First record of damage by an insect pest in a commercial amaranth crop in Brazil. Sci Agr 69:271-274

Downton WJS (1973) Amaranthus edulis: a high lysine grain amaranth. World Crops 25:20

El-Aydam M, Bürki HM (1997) Biological control of noxious pigweeds in Europe: a literature review of the insect species associated with Amaranthus spp. worldwide. Biocontrol 18:11-20

Guerrero MA, Lamborot L, Araya JE (2000) Observaciones biológicas de Achyra similalis (Guenèe) (Pyralidae) y otros lepidópteros en amaranto, Amaranthus cruentus L. (Amaranthaceae), en la Región Metropolitana de Chile. Boletín Sanidad Vegetal Plagas 26:591-598

Gültekin L, Korotyaev BA (2012) New data on Cosmobaris discolor (Boheman) and Hypolixus pica (F.) (Coleoptera: Curculionidae) associated with Amaranthus (L.) (Amaranthaceae). Coleopts Bull 66: 226-232

Henderson T, Schneiter A, Johnson B, Riveland N, Schatz BG (1993) Production of amaranth in the northern Great Plains. In: Alternative crop and alternative crop production research. A progress report. North Dakota State University, Fargo, pp 22-30

Jena BC, Mohanty SK, Mishra PR (2000) Grain Amaranthus varieties and their insect pests. Indian J Entomol 62:314-316

Jha PK, Sah JP, Chettri MK (1992) Amaranth productivity under biological stresses. Crop Res 5:195-198

Johnson BL, Henderson TL (2002) Water use patterns of grain amaranth in the Northern Great Plains. Agron J 94:1437-1443

Kauffman CS, Weber LE (1990) Grain amaranth. In: Janick J, Simon JE (eds) Advances in new crops. Timber Press, Portland, pp 127-139

Keane RM, Crawley MJ (2002) Exotic plant invasions and the enemy release hypothesis. Trends Ecol Evol 17:164-170

Kolaib MO, Younes MWF, Darwish ETE (1986) Hypolixus nubilosus as a factor in biological control of Amaranthus weeds in Egypt. Ann Agric Sci 31:767-775
Liu H, Stilling P (2006) Testing the enemy release hypothesis: a review and meta-analysis. Biol Invasions 8:1535-1545

Liu F, Stützel H (2002) Leaf expansion, stomatal conductance and transpiration of vegetable amaranth (Amaranthus sp.) in response to soil drying. J Am Soc Hortic Sci 127:878-883

Louw S vdM, Myburgh E (2000) Occurrence and prominence of insect guilds on vegetable amaranth (Amaranthus hybridus) cultivated in the central Free State, South Africa. Afr Plant Prot 6:9-16

Louw S, Van Eeden CF, Weeks WJ (1995) Curculionidae (Coleoptera) associated with wild and cultivated Amaranthus spp. (Amaranthaceae) in South Africa. Afr Crop Sci J 3:93-98

Mujica A, Berti M (1997) El cultivo del amaranto (Amaranthus sp.): producción, mejoramiento genético y utilización Oficina Regional de la FAO para América Latina y el Caribe, Santiago, Chile, y la División de Producción y Protección de Plantas, Roma, Italia. $145 \mathrm{pp}$

Mujica SA, Quillahuamán A (1989). Phenology of kiwicha (Amaranthus caudatus L.). In: Workshop course of Andean crop phenology and use of agro meteorological information. Puno, 7-10 August. INIA, PICA. Perú, pp. 29-31

Napompeth B (1982) Biological research development in Thailand. In: International Conference on Plant protection Tropics. Kuala Lumpur, 1-4 March 1982, pp 301-323

Olson DL, Wilson RL (1990) Tarnished plant bug (Hemiptera: Miridae): effect on seed weight of grain amaranth. J Econ Entomol 83:24432447

Omami EN, Hammes PS (2006) Interactive effects of salinity and water stress on growth, leaf water relations, and gas exchange in amaranth (Amaranthus spp.). New Zeal J Crop Hort 34:33-44

Pedersen B, Bach-Knudsen KE, Eggum BO (1990) The nutritive value of amaranth grain (Amaranthus caudatus). Energy and fiber of raw and processed grain. Plant Food Hum Nutr 40:61-71

Pérez-Torres BC, Aragón-García A, Pérez-Avilés R, Hernández LR, LópezOlguín JF (2011) Entomofaunistic study in of the cultivation of Amaranth (Amaranthus hypochondriacus L.) in Puebla, México. Rev Mex Cienc Agríc 2:359-371

Phogat BS, Bhalla S, Mal B (1994) Seasonal incidence of stem weevil (Hypolyxus truncatulus) and its effect on growth and grain yield of amaranth (Amaranthus hypochondriacus). Indian J Agr Sci 64:261262

Riquelme VMV, Ansa MA, Santadino MV (2013) Preferencia de oviposición del barrenador del amaranto, Aerenea quadriplagiata (Coleoptera, Cerambycidae) en condiciones de campo. Rev Colomb Entomol 39:76-80

Robertson KR (1981) The genera of Amaranthaceae in the Southeastern United States. J Arnold Arboretum 62:267-313

Salas-Araiza MD, Boradonenko A (2006) Insectos asociados al amaranto Amaranthus hypochondriacus L. (Amaranthaceae) en Irapuato, Guanajuato, México. Acta Universitaria 16:50-55

Sauer YD (1950) The grain amaranths: a survey of their history and classification. Ann Mo Bot Gard 37:561-632

Sauer YD (1967) The grain amaranths and their relatives: a revised taxonomic and geographic survey. Ann Mo Bot Gard 54:103-137

Schuester M (1987) Blister beetle in Paraguay-a potential biological control agent. Trop Pest Manage 33:241

Spencer KA (1969) The Agromyzidae of Canada and Alaska. Mem Ent Soc Can 101:5-311

Spencer KA (1973) Agromyzidae (Diptera) of economic importance. Series Entomologica Dr. W Junk. Hague 9:1-418

Spencer KA, Havraneck D (1989) A new species of Agromyzidae (Diptera) from Venezuela. Fla Entomol 72:441-444

Stegmaier CE (1950) Insects associated with the rough pigweed, Amaranthus retroflexus L. (Amaranthaceae). PhD Thesis, Kansas State College of Agriculture and Applied Science

Stork NE (1987) Guild structure of arthropods from Bornean rain forest trees. Ecol Entomol 12:69-80 
Strong DR, Lawton JH, Southwood R (1984) Insects on plants: community patterns and mechanisms. Blackwell Scientific Publications, Oxford

Terry LI, Lee CW (1990) Infestation of cultivated Amaranthus by the weevil Conotrachelus seniculus in southeastern Arizona. Southwest Entomol 15:27-31

Teutonico RA, Knorr D (1985) Amaranth: composition, properties, and applications of a rediscovered food crop. Food Tech 39:49-60

Vasicek A, Ricci E, Mitidieri A (1998) Evaluación del comportamiento de Conotrachelus histrio Boh. (Coleoptera: Curculionidae) "barrenador del tallo" de Amaranthus quitensis HBK. en cultivo de soja. Revista Amarantos, Facultad de Agronomía. UNLPam 22:3-12

Ves Losada JC, Covas G (1987) Lista preliminar de artrópodos que afectan a los amarantos en la provincia de La Pampa. In: Proceedings of I
Jornadas Nacionales sobre Amarantos. Facultad de Agronomía UNLPam, La Pampa, Argentina, pp 109-111

Waterhouse DF (1994) Biological control of weeds: Southeast Asian prospects. ACIAR Monograph n 26. Canberra, Australia; Australian Centre of International Agricultural Research, pp. 18-24.

Weber LE, Hubbard ES, Nelson LA, Putnam DH, Lehmann JW (1988) Amaranth grain production guide. Rodale, Emmaus

Wilson RL (1990) Insects and disease pests of Amaranthus. In: Proceedings of the Fourth National Amaranth Symposium: Perspectives on production, processing and marketing. University of Minnesota, St. Paul. Minnesota, pp 163-169

Zannini E, Jones MJ, Renzetti S, Arendt EK (2012) Functional replacements for gluten. Annu Rev Food Sci T 3:227-245 